\title{
A CROSS SECTIONAL STUDY ON THE THYROID PROFILE OF NEONATES BORN TO HYPOTHYROID MOTHERS IN A TERTIARY CARE CENTRE IN CHENNAI
}

\section{P. GUNASUNDARI ${ }^{\mathrm{a} 1}$, MURALIDHARAN SATHYAMOORTHY ${ }^{\mathrm{b}}$, CHRISTINA MARY P. PAUL ${ }^{\mathrm{c}}$, KALAVATHY VICTOR ${ }^{\mathrm{d}}$, I. PREETHI EVANGELINE ${ }^{\mathrm{e}}$, A. KIRAN ${ }^{\mathrm{f}}$ AND S. KARAN KUMAR ${ }^{\mathrm{g}}$}

${ }^{\text {abcdefg }}{ }^{D e p a r t m e n t ~ o f ~ P e d i a t r i c s, ~ A C S ~ M e d i c a l ~ C o l l e g e ~ \& ~ H o s p i t a l ~(D r . ~ M . G . R . ~ E d u c a t i o n a l ~ a n d ~ R e s e a r c h ~ I n s t i t u t e), ~ V e l a p p a n c h a v a d i, ~}$ Chennai, Tamilnadu, India \begin{abstract}
Difference
Congenital hypothyroidism $(\mathrm{CH})$ occurs approximately $1: 2000$ to $1: 4000$ new borns. The clinical manifestations are often subtle and not present at birth This is likely to due to the tranplacental passages of some maternal thyroid hormones while many infants have some thyroid production of there own. $\mathrm{CH}$ is one of the most common preventable cause of mental retardation. Among thyroid hormones if free $\mathrm{T}_{4}$ level is low and TSH level is elevated a diagnosis of $\mathrm{CH}$ is confirmed. The prevalence of $\mathrm{CH}$ generally has no relationship with maternal hypothyroidism state \& treatment with thyroxine in antenatal mothers. New borns can have devastating neuro developmental consequences if not detected and treated promptly. Screening procedures for $\mathrm{CH}$ have developed in many countries \& it has virtually eradicated intellectual disability due to severe $\mathrm{CH}$. Screening has resulted in increased detection of mild $\mathrm{CH}$. The underlying cause reminds obscure in many cases. Thyroid hormone is essential for normal growth \& neurological development particularly in first few years of life. Hypothyroidism during this period may damage the growth \& development.
\end{abstract}

ABSTRACT

Retrospective study was done to estimate the prevalence of congenital hypothyroidism $(\mathrm{CH})$ among new born babies born to hypothyroid mothers on thyroxine in ACS Medical College \& Hospital. Datas were collected from the case sheets in medical record department. The prevalence of $\mathrm{CH}$ was 1 in 2500 live births with no gender difference.

KEYWORDS: Congenital Neonatal Hypthyroidism, New Borns, Hypothyroidism in Antenatal Mothers, No Gender

\section{MATERIALS AND METHODS}

From new borns blood is taken by prick method for screening. Blood is collected between 2-5 days preferably after 72 hours . Estimation is done by ELISA method. New borns with abnormal results are reviewed and venepuncture blood sample are drawn for confirmation. Free $\mathrm{T}_{4}$, TSH results are compared to age normal reference ranges \& treatment should be started as early as possible. The present study was conducted in the department of paediatrics \& in neonatal intensive care unit. ACS Medical College \& Hospital from January
2016 to September 2019. It was a retrospective study of congenital hypothyroidism Proforma was used to record information on age, sex, birth weight, mode of delivery, antenatal mother on thyroxine (regular/irregular) treatment. Investigations like free $\mathrm{T}_{3}, \mathrm{~T}_{4}, \mathrm{TSH}$ levels were estimated.

\section{Inclusion Criteria}

New borns between 2-5 days born to hypothyroid mothers were included.

\section{Exclusion Criteria}

New borns below 48 hours \& above 5 days were excluded.

Table 1: Background Variables of the Study Subjects

\begin{tabular}{|c|c|c|c|}
\hline \multirow{2}{*}{ Variable } & $\begin{array}{c}\text { Classification } \\
\text { of Variable }\end{array}$ & $\begin{array}{c}\text { Number } \\
\text { (out of 80) }\end{array}$ & \% \\
\hline \multirow{2}{*}{$\begin{array}{c}\text { Mode of } \\
\text { birth }\end{array}$} & Vaginal & 8 & 10 \\
\cline { 2 - 4 } Gender & C- section & 72 & 90 \\
\cline { 2 - 4 } & Male & 39 & 48.8 \\
\hline \multirow{2}{*}{$\begin{array}{c}\text { Birth } \\
\text { weight }\end{array}$} & Female & 41 & 51.2 \\
\cline { 2 - 4 } & $\geq 3 \mathrm{kgs}$ & 61 & 76.3 \\
\hline
\end{tabular}

Table 2: Thyroid profile of the study subjects

\begin{tabular}{|c|c|c|c|}
\hline Parameter & Mean & $\begin{array}{c}\text { Standard } \\
\text { Deviation, } \\
\text { Standard Error }\end{array}$ & 95\% C. I \\
\hline T-3 & 1.09 & $0.53,0.06$ & $0.97-1.21$ \\
\hline T-4 & 7.75 & $3.47,0.39$ & $6.99-8.51$ \\
\hline TSH & 3.79 & $3.53,0.39$ & $3.03-4.52$ \\
\hline
\end{tabular}




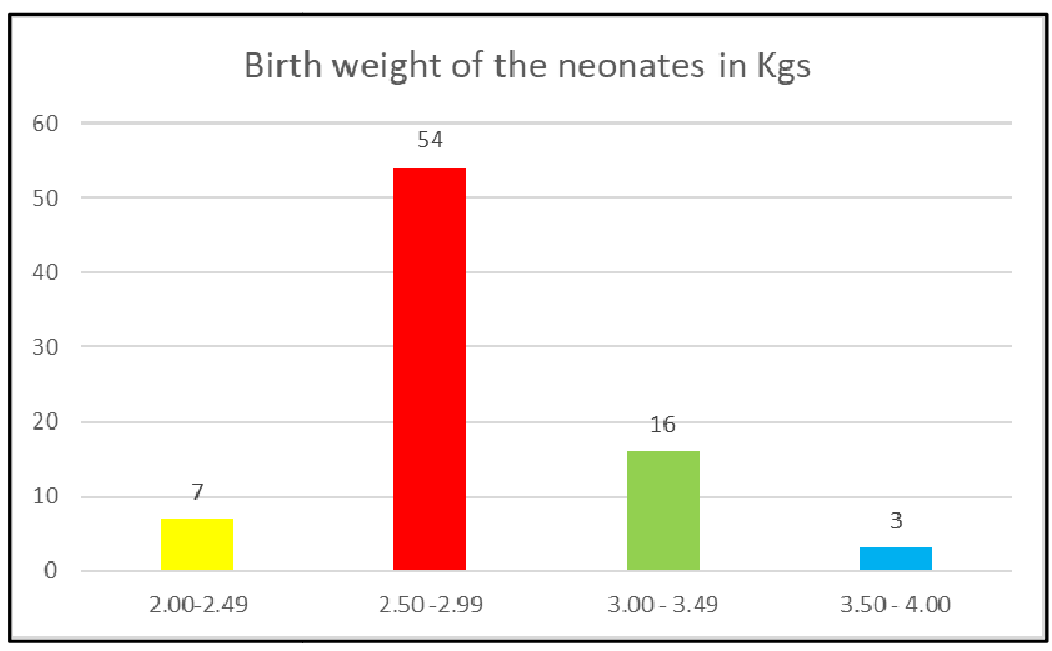

Figure 1: Graphical representation of the birthweight of the babies

Table 3: Prevalence of hypothyroidism in neonates born to mothers with hypothyroidism

\begin{tabular}{|c|c|c|c|}
\hline $\begin{array}{c}\text { Total Number of } \\
\text { Neonates }\end{array}$ & $\begin{array}{c}\text { Number with } \\
\text { Hypothyroidism }\end{array}$ & Percentage & 95\% C. I \\
\hline 80 & 2 & 2.5 & $-0.92-5.92$ \\
\hline
\end{tabular}

Table 4: Association between birthweight of the baby and certain factors

\begin{tabular}{|c|c|c|c|c|c|}
\hline \multirow{2}{*}{ Variable } & $\begin{array}{c}\text { Classification of } \\
\text { variable } \\
\text { (number of people in } \\
\text { the group out of 80) }\end{array}$ & $\begin{array}{c}\text { Number of subjects } \\
\text { who had babies with } \\
\text { birthweight less than } \\
\mathbf{3} \text { kgs (out of 61) }\end{array}$ & $\begin{array}{c}\text { Odds ratio } \\
\text { (95\% C. I of } \\
\text { odds ratio) }\end{array}$ & $\begin{array}{c}\text { Chi - } \\
\text { square } \\
\text { value }\end{array}$ & P - value \\
\hline \multirow{2}{*}{ Gender } & Male (39) & 32 & $1.89(0.66-5.45)$ & \multirow{2}{*}{1.41} & 0.23 \\
\cline { 2 - 4 } Mode of birth & Female (41) & 29 & 1.00 & \multirow{2}{*}{0.12} & 0.73 \\
\cline { 2 - 4 } & Vaginal (8) & 7 & 54 & 1.00 & $0.27-20.28)$ \\
\hline
\end{tabular}

\section{RESULTS}

During the followup, monitor growth \& development, compliance, symptoms, free $\mathrm{T}_{4} \& \mathrm{TSH}$ Thyroid hormone enhances the growth with growth hormone. Increased BMR, increased heart rate, decreased cholestrol level and maintaining thermogenesis. Hence children with hypothyroidism have poor growth, hypothermia, lethargy and bradycardia.

\section{OBSERVATION}

On analysis of 100 cases $90 \%$ of the deliveries were caeserian section, $10 \%$ was vaginal delivery. That is due to mainly because of large babies. Regarding sex distribution males $49 \%$ and females $51 \%$. Almost no gender difference, it was very marginal. Birth weight was more than $3 \mathrm{~kg}$ in $76 \%$ and less than $3 \mathrm{~kg}$ in $24 \%$. Only 2 neonates were found to be in hypothyroid state. Male:Female 1:1

\section{DISSCUSION}

The thyroid gland is the largest single organ in the body specialized for endocrine hormone production. Its function is to secrete an appropriate amount of thyroid hormone, Tetra $\left(\mathrm{T}_{4}\right) \&$ Tri iodothyronine $\left(\mathrm{T}_{3}\right)$. Iodine is trapped by thyroid and produce thyroglobulin and converted to tri iodo \& di iodo thyroxine. Coupling with thyroglobulin occurs. Block in the synthesis at any level will lead to congenital hypothyroidism. In Primary Hypothyroidism $\mathrm{T}_{4}$ decreases and high $\mathrm{TSH}$ is seen. Secondary Hypothyroidism free $\mathrm{T}_{4}$ is decreased and low TSH. TSH is secreted by hypothalamus and regulated by thyrotrophic hormone. There is physiological surge in $\mathrm{TSH}$ in the first 48 hours of life because of cooling, cord 
clamping and stress of birth. Hence screening using either cord blood or heel prick after 72 hours of life should be done to avoid false positive results. Maternal thyroxine may mask the clinical features of hypothyroidism in neonates. Hence it is mandatory to screen all neonates for congenital hypothyroidism as it is a preventable cause of mental retardation. Since the screening test is a sensitive test primary TSH approach is followed in our country. Maternal antibodies and iodine can cross the placenta and block neonatal thyroid functiom. Hence watch the babies for transient hyothyroidism. Only $0.25 \%$ of $\mathrm{T}_{4}$ and $0.35 \%$ of $\mathrm{T}_{3}$ are free. Hence free $\mathrm{T}_{3}$ hormone concentration correlates with the thyroid state.

Levothyroxine is the treatment of choice 10-15 $\mu \mathrm{g} / \mathrm{kg} /$ day as the initial dose given as single dose in the morning crushed and mixed with breastmilk or water. Neonatal hypothyroidism if not treated immediately it will produce irrversible injury. The incidence is higher in asian indviduals \& lower in blacks. The incidence is greater in females than males. Down syndrome babies are at risk. $85 \%$ of cases are due to thyroid dysgenesis and $15 \%$ are due to dyshormonogenesis. Thyroid radionucleotide uptake $\&$ scanning are the most accurate imaging tests to define the size and location of any thyroid tissue. Family hypothyroidism, mother or close relatives taking thyroid tablets, undergone thyroid surgery or physical signs \& symptoms of hypothyroidism should be evaluated by paediatrics \& endocrinologist definitive ones are increased TSH and decreased $\mathrm{T}_{4}$ levels.

\section{ACKNOWLEDGEMENT}

We deeply acknowledge the help rendered by paediatric \& NICU Department, record office staff and Ms. Preethi Evangeline. I ACSMCH for their valuable contributions. The author would like to thank especially Dr. Christina Mary P. Paul MD \& Prof. of Community Medicine ACSMCH for her constant inspiration and support.

\section{REFERENCES}

Bhatia V., 2010. Congenital hypothyroidism is not always permanent: caveats to newborn thyroid screen interpretation. Indian Pediatr., 47: 753-54.

Desai M.P., 2012. Congenital hypothyroidism: screening dilemma. Indian J. Endocrinol Metab., 16: 1535 .

Dilli D., Czba, Acican D., Yamak N., Ertek M. and Dilmen U., 2013. Establishment and development of a national newborn screening programme for congenital hypothyroidism in Turkey. J. Clin. Res. Pediatr. Endocrinol., 5: 739.

Kaur G., Srivastav J., Jain S., Chawla D., Chavan B.S. and Atwal R., 2010. Preliminary report on neonatal screening for congenital hpothyroididsm, congenital adrenal hyperplasia and glucose-6-phosphate dehydrogrnase deficiency; A Chandigarha experience. Indian J. Pediatr., 77: 969-73.

Manglik A.K., Chatterjee N. and Ghosh G., 2005. Umbilical cord blood TSH levels in term neonates: a screening tool for congenital hypothyroidism. Indian J. Pediatr., 42: 1029-32.

Nascimento M.L., Silva P.C., Simoni G., Lobo G.S. and Souza C.D., 1997. Congenital Hypothyroidism screening programme preliminary results. J. Pediatr. (Rio J), 73: 176-9.

Ordookhani A., Mirmiran P., Najafi R., Hedayati M. and Azizi F., 2003. Congenital hypothyroidismcin Iran . Indian J. Pediatr., 70: 625-8.

Sanghvi U. and Diwakar K.K., 2008. Universal screening for congenital hypothyroidism. Indian Pediatr., 45: $331-2$.

Wu L.L., Sazali B.S., Adeep N. and Khalid B.A., 1999. Congenital hypothyoid screening using cord blood TSH. Singapore Med. J., 40: 23-6. 